\title{
The Effect on School Productivity of Principal and Scholastic Culture
}

\author{
Arysta Sari ${ }^{1 *}$, Bukman $\operatorname{Lian}^{2}$, Rohana $^{2}$ \\ ${ }^{1}$ SMP Negeri $41 \mathrm{OKU}$ \\ ${ }^{2}$ Universitas PGRI Palembang \\ *Corresponding author. Email: sari.arysta@gmail.com
}

\begin{abstract}
This research aims at determining the impact on productivity at the same time of the principal's leadership and the School community. This study uses quantitative methods with a total population of around 121 respondents consisting of junior high school principals, teachers, and education personnel in Baturaja Barat District. In this study, the sample consisted of 100 respondents. The sampling technique in this study uses the Slovin formula with a 5\% error margin. Questionnaire is used for collecting data. The data were analysed using the SPSS Program Version 25. The analysis found that the principal's leadership and school culture concurrently affected the competitiveness of schools in Baturaja Barat.
\end{abstract}

Keywords: Principal's Leadership, School Culture, School Productivity

\section{INTRODUCTION}

Improvement of the standard of education in schools today is a challenge and hope for schools. Rahmat in Susanto [1] noted several facts related to the quality of educational institution graduates. First, the result of the national examination in 2008 showed that students failing to pass reached around $11 \%-12 \%$ or around 250.000 students out of 2.260 .148 students. The percentage of failures was higher than in 2007 which reached $10 \%$ only. Secondly, the limited number of students qualified to be admitted to public and private chosen universities. Third, the student who is involved in different acts of violence has a poor level of conduct and morality. Fourth, the number of graduates of high school who didn't continue their studies at tertiary institutions and graduates of technical education who were not absorbed by the world of work.

The low productivity of schools is indirectly indicated by this evidence. As an institution that generates quality and skilled human capital, schools must work effectively and efficiently as criteria for the productivity of an organization. The low productivity in school is caused by several factors. As concluded in the result of research conducted by Thomas [2], which indicates that Factors that affect school effectiveness include consistency of the operation, teaching skills, organizational culture, finance, school leadership and a position for the school board. From the result of research conducted by Sobandi and Saud [3], it is reported that the leadership of the principal and the school environment directly or indirectly significantly influences school productivity. If it is assisted by strong principal leadership who is willing to change the school environment itself, school productivity would be higher. In the result of his study, Noerdin [4] indicates that collaboration between teachers and school principals is required to achieve school productivity so that achievement can be more optimal, which can be seen in the leadership of the principal and teacher success as a form of collaboration. More precisely, Susanto [1] noted that the principal's leadership, teacher competence, school environment, staff morale, school organizational culture, learning quality, school operating costs, student economic context, technology usage, and facilities and infrastructure are factors that influence school productivity. Sobandi [5] suggests that the principal's leadership, teacher teaching efficiency, school environment, and learning facilities affect school productivity. The headmaster has to practice imagination, guide all the participants and the school as an educational institution through the talents, skills and abilities of its members to change their mind and improve their vision and goals [6]. The leadership style adopted by the Principal will help the Principal's results and effective guidance and delivery of the school education process [7]. The leadership must be able to 
influence others or staff as leaders in a leadership-style [8].

It can be concluded from some of the above results that the leadership of the principal and the tradition of schools play an important role in the performance of schools. That is to say, the leadership and school culture of the principal will affect the competitiveness of the school. According to the researcher, it is important to examine, based on the reasons, viewpoints and analysis that were described, how the principal's leadership and school culture affects school effectiveness.

\section{METHODS}

This research uses non-experimental quantitative research. The method of analysis used in this research is the method of inference. The research population consisted of 121 people, which included directors, teachers and staff from the West Baturaja State Junior Schools. The study included 100 participants. The survey was in this analysis, the sampling methodology used Slovin measurements with a 5 percent error margin. A questionnaire was used for data collection. The data from the analysis will be evaluated in normality testing, heteroscedasticity testing and multicollinearity testing with the classical assumption test. Hypothesis testing will be analysed using the F test. This analysis includes three variables, each with descriptions of two independent variables, namely the main leadership $\left(\mathrm{X}_{1}\right)$ and the culture of the school $\left(\mathrm{X}_{2}\right)$ (Y). Analysis of the data was conducted using SPSS Version 25.

\section{RESULTS AND DISCUSSION}

The normality test is carried out to determine whether or not variable data is usually transmitted. Data that is normally distributed means that it has a normal distribution as well. The level of normality of the data is considered important because data that is normally distributed shows that the data can represent the population. The findings of this study's vector normality test are shown in the table below.

Table 1. Test of Normality

\begin{tabular}{|c|c|c|}
\hline Variable & $\begin{array}{c}\text { S } \\
\text { ig. }\end{array}$ & $\begin{array}{c}\text { Informa } \\
\text { tion }\end{array}$ \\
\hline $\begin{array}{c}\text { Unstandardized } \\
\text { Residual }\end{array}$ & $\begin{array}{c}0, \\
085\end{array}$ & Normal \\
\hline
\end{tabular}

According to the findings in table 1, the unstandardized residual value has a significance value of 0.085 , which is greater than 0.05 , implying that the data used in this analysis are usually distributed.

A heteroscedasticity test is used to determine if the residuals in a linear regression model have an inequality of variance for all observations. If the assumption of heteroscedasticity is not met, the regression model is declared useless as a forecasting method. The following table shows the results of the heteroscedasticity test used in this analysis.

Table 2. Test of Heteroscedasticity

\begin{tabular}{|c|c|c|}
\hline Variable & . $\quad$ Sig & Information \\
\hline $\begin{array}{l}\text { Principal's } \\
\text { Leadership }\end{array}$ & $41^{0,6}$ & $\begin{array}{l}\text { Non- } \\
\text { Heteroscedasticity }\end{array}$ \\
\hline $\begin{array}{l}\text { School } \\
\text { Culture }\end{array}$ & $58^{0,1}$ & $\begin{array}{l}\text { Non- } \\
\text { Heteroscedasticity }\end{array}$ \\
\hline
\end{tabular}

greater than 0.05 , the regression model does not show

The significance value of the principal's leadership variable $\left(\mathrm{X}_{1}\right)$ for absolute residual is 0.641 , according to the data in table 2. For absolute residuals, the significance value of the school culture vector $\left(\mathrm{X}_{2}\right)$ is 0.158 . Since both variables have a significance value any signs of heteroscedasticity (non-heteroscedasticity).

The multicollinearity test results in this study can be seen in the following table. 
Table 3. Test of Multicollinearity

\begin{tabular}{|c|c|c|c|}
\hline Variable & $\begin{array}{c}\text { Tole- } \\
\text { rance }\end{array}$ & $\begin{array}{c}\text { VI } \\
\text { F }\end{array}$ & Information \\
\hline Principal's Leadership & 0,979 & 1,0 & $\begin{array}{c}\text { Non-Multi } \\
\text { collinearity }\end{array}$ \\
\hline School Culture & 0,979 & $\begin{array}{c}1,0 \\
\text { Non-Multi } \\
\text { collinearity }\end{array}$ \\
\hline
\end{tabular}

The tolerance value for the principal's leadership variable $\left(\mathrm{X}_{1}\right)$ and school culture $\left(\mathrm{X}_{2}\right)$ is 0.979 , according to the data in table 3 . For both variables, the tolerance value is greater than 0.10 . The VIF value of the two variables is then 1.022, which is less than 10.00. As a result, the regression model can be interpreted as having no multicollinearity (non-multicollinearity).

Table 4. Multiple Linear Regression Analysis

\begin{tabular}{|c|c|c|c|}
\hline Variable & $\begin{array}{c}\text { Unstandardized } \\
\text { Coefficients B }\end{array}$ & $\mathbf{T}$ & $\begin{array}{l}\text { Sig } \\
\text {. }\end{array}$ \\
\hline Principal's Leadership & $-0,271$ & $\begin{array}{r}- \\
2,393\end{array}$ & $\begin{array}{c}0,0 \\
19\end{array}$ \\
\hline School Culture & $-0,287$ & $\begin{array}{r}- \\
2,505 \\
\end{array}$ & $\begin{array}{l}0,0 \\
14 \\
\end{array}$ \\
\hline Constant & \multicolumn{3}{|c|}{$=126,119$} \\
\hline R Square & \multicolumn{3}{|c|}{$=0,126$} \\
\hline $\mathrm{F}$ & \multicolumn{3}{|c|}{$=7,023$} \\
\hline Sig. & \multicolumn{3}{|c|}{$=0,001$} \\
\hline
\end{tabular}

On the basis of F-test performance, mean 0.001 $(p<0.05)$ was obtained and the measured F-value 7,023 which is higher than F-table 3.09. In the West Baturaja District, the leadership and school culture affect the competitiveness of public secondary schools. The R Square value of 0.126 indicates the magnitude of the effect of the two independent variables on the dependent variable. This means that the leadership of the principal and school culture together on the productivity of public junior high schools in West Baturaja District influences of $12.6 \%$.

The resulting importance in this study shows that school efficiency is influenced concurrently by principal leadership and school culture. This study is supported by earlier research Sujaya [9] that shows that main leadership and the school culture alone and simultaneously exert a major impact on the productivity of schools. At the same time, both main management and school culture contribute to the success of schools, the better the principal leadership and school culture, the more school productivity will increase.

The findings of the research Achdi [10] show that the main leadership and school culture have a major impact on the productivity of schools individually and at the same time. Simultaneously, both principal leadership and school culture contributed to school productivity by 0.962 with a determination coefficient of $92.5 \%$, while the remaining $6.5 \%$ was influenced by several other factors such as 1) the competence or ability of teachers and school leaders; 2) the motivation of teachers and school leaders; and 3) quality of work life.

\section{CONCLUSION}

The main leadership and school culture have a simultaneous impact on the productivity of the West Baturaja District Public Junior Schools. The measured F value $>\mathrm{F}$ table demonstrates this. The determination coefficient between the independent variables is 0.126 . This demonstrates that the variable of leadership and education at the same time influences the efficiency of high schools in the West Baturaja district by 12.6 percent. In this study, however, the other $87.4 \%$ are influenced by other factors not variables.

\section{ACKNOWLEDGMENTS}

Our deepest gratitude goes to Teachers in SMP Negeri 41 OKU, Chancellor of Palembang PGRI University, Director of the Postgraduate Program of PGRI Palembang University and the Education Management Study Program of PGRI Palembang University, who have supported us in doing this extraordinary thing. This project is funded independently. We also want to thank our Education 
Management friends who helped us a lot in a short time frame to complete this project.

\section{REFERENCES}

[1] Susanto, P. (2016). Produktivitas Sekolah Teori untuk Praktik di Tingkat Satuan Pendidikan. Bandung: Alfabeta.

[2] Thomas, P. (2013). Faktor Determinan Produktivitas Sekolah. Jurnal Penelitian dan Evaluasi Pendidikan, 17(1), 55-71. http://doi.org/10.21831/pep.v17i1.1361

[3] Sobandi, A., dan Saud, U. S. (2016). Principal Leadership, School Climate, and School Productivity at Vocational School in Bandung. Advances in Economics, Business and Management Research, 15, 544-548. https://doi.org/10.2991/gcbme-16.2016.99

[4] Noerdin, M. A. (2016). Pengaruh Kepemimpinan Kepala Sekolah dan Kinerja Mengajar Guru terhadap Produktivitas Sekolah pada Sekolah Dasar Negeri di Kabupaten Bandung Barat [Tesis]. Bandung (ID): Universitas Pendidikan Indonesia. http://repository.upi.edu/id/eprint/27671

[5] Sobandi, A. (2015). Produktivitas Sekolah Menengah Kejuruan: Studi tentang Pengaruh Kepemimpinan Kepala Sekolah, Kinerja Mengajar Guru, Iklim Sekolah dan Fasilitas Pembelajaran terhadap Produktivitas SMK Bidang Keahlian Bisnis dan Manajemen di Kota Bandung [Disertasi]. Bandung (ID): Universitas Pendidikan Indonesia. http://repository.upi.edu/id/eprint/21589

[6] Andriani, S., Kesumawati, N., \& Kristiawan, M. (2018). The Influence of the Transformational Leadership and Work Motivation on Teachers Performance. International Journal of Scientific \& Technology Research, 7(7).

[7] Astuti, R. W., Fitria, H., \& Rohana, R. (2020). The Influence of Leadership Styles and Work Motivation on Teacher's Performance. Journal of Social Work and Science Education, 1(2), 105-114. Retrieved from https://ejournal.karinosseff.org/index.php/jswse/arti cle/view/33

[8] Asvio, N., Yamin, M., \& Risnita. (2019). Influence of Leadership Style, Emotional Intelligence and Job Satisfaction toward Organizational Commitment (Survey at SMA Muhammadiyah South Sumatera). International Journal of Scientific \& Technology Research 8 (8).

[9] Sujaya, K. (2012). Kontribusi Kepemimpinan Kepala Sekolah, Budaya Sekolah, Kinerja Guru dan Pendanaan Sekolah terhadap Produktivitas Sekolah: Studi pada SMAN di Wilayah Priangan Timur [Disertasi]. Bandung (ID): Universitas Pendidikan Indonesia. http://repository.upi.edu/id/eprint/7855

[10] Achdi. (2010). Pengaruh Kepemimpinan Kepala Sekolah dan Budaya Sekolah terhadap Produktivitas Sekolah di Kabupaten Sumedang (Studi Analisis Deskriptif pada SMA Negeri dan Swasta di Kabupaten Sumedang) [Tesis]. Bandung (ID): Universitas Pendidikan Indonesia. http://repository.upi.edu/id/eprint/9976 